\title{
Funkční charakteristiky hráčů fotbalu
}

\section{Determinations of functional characteristics of soccer players}

\author{
Jaroslav Teplan, Tomáš Malý, Pavel Hráský, František Zahálka, Aleš Kaplan, \\ Lucía Malá, Jan Heller
}

Fakulta tělesné výchovy a sportu Univerzity Karlovy v Praze

\begin{abstract}
Abstrakt
Cílem předložené studie je shrnout detailní a sofistikované př́stupy v hodnocení pohybových nároků a indikátorů na funkční charakteristiky hráču fotbalu. Kličové body řešené v přehledové studii jsou model pohybové struktury hráče v utkáni a fyziologické parametry, které mohou ovlivňovat výkon hráče v utkání.

Fyziologické parametry a model pohybové struktury ve fotbale jsou řešeny v radě studii a neustále se zdůrazňuje potřeba sofistikovaného vědeckého přístupu na výkon hráče v utkání. V přehledové studii vycházíme z výsledků a závěrů studií publikovaných v zahraničních vědeckých časopisech či př́íspěvků prezentovaných na významných védeckých konferencích.

Hráčské posty jsou charakterizovány odlišnými nároky v modelu pohybové struktury či bioenergetického výdeje a při plánování tréninkového procesu by se měly tyto aspekty respektovat. Hráči během utkání musí v krátkém časovém intervalu reagovat na zmèny smèru či zvládnout fotbalovou lokomoci $v$ príslušné intenzitè.

Během utkání se z hlediska intenzity zatížení překrývají aerobní a anaerobní metabolismus. Hráč musí $v$ utkáni provádět opakovanè činnosti ve vysoké intenzitě s rychlou obnovou energetických zdrojů a maximálním oddálením nastupující únavy. Rozdíl mezi hráči elitní a nižši úrovně je v objemu vykonávaných pohybových činností ve vysokých intenzitách. Vlivem únavy ke konci utkání u hráčů dochází ke snížení úrovně jemné koordinace a provedení technických dovedností.

Na základě prehledových studií byly zjištěny různé pohledy a determinanty na funkční pripravenost hráče. Dominantní úlohu sehrávají následující kritéria: hráčská úroveň (profesionál, amatér apod.), soutěž (mezinárodní, národní apod.), hráčský post, úkoly hráče, fáze utkání a rozestavení hráču.
\end{abstract}

\begin{abstract}
The aim of this contribution is to summarize the state of the functional characteristics of soccer players. The key points addressed in the study are motion model structures player in the game and physiological parameters that can affect a player's performance in the match. Physiological parameters and model physical structures in football are addressed in a number of studies and constantly stress the need for sophisticated scientific approach to the player's performance in the game.

In the survey study, we proceed from the results and conclusions of studies published in foreign scientific journals or presented at important posts of scientific conferences. Player positions are characterized by distinct physical demands in the model motion structure and bioenergetic expenditure and planning training process should respect the following aspects. Players must match within a short period of time to react to changes in direction or manage football in the intensity of locomotion. During the match aerobic and anaerobic overlap metabolism in terms of intensity loads. The player must repeatedly perform in a match of high intensity activity with rapid recovery of energy resources and delaying the maximum fatigue emerging.

The difference between elite players and lower level is the amount of physical activities performed at high intensities. Due to fatigue at the end of the game players appear less smooth coordination and implementation of technical skills. Based on surveillance studies different views and determinants of the functional readiness of the player were identified. The dominant role is played by the following criteria: player's level (professional, amateur, etc.), competition (international, national, etc.), post player, tasks player's stage game and game system.
\end{abstract}




\section{Klíčová slova: fotbal, model pohybovéstruktury, utkání, aerobní metabolismus, anaerobní metabolismus, únava}

Keywords: $\quad$ soccer, model motion structure, match, aerobic metabolism, anaerobic metabolism, fatigue

Př́spèvek vznikl v rámci Výzkumného záměru MŠMT ČR MSM 0021620864, s podporou projektu SVV 2012-265603 a GAČR P407/11/P784.

\section{Úvod}

Pro realizaci sportovního tréninku je důležité znát požadavky jednotlivých sportů, ve kterých se prolínají složky kondiční, technické, taktické či psychické. Požadavky individuálních sportů na přípravu sportovců jsou více identifikovatelné než u sportovních her, kde je příprava sportovců složitější (Silva et al. 2008). Musíme v nich brát ohled na jednotlivé hráče, kteří musí mezi sebou spolupracovat, aby dosáhli společného cíle. Každý hráč má odlišné kondiční předpoklady, technické dovednosti, taktické myšlení a psychické vlastnosti, a proto má v týmu svoji roli. Úkolem trenéra ve sportovních hrách je využít tyto dispozice u každého hráče výběrem správného rozestavení. Tím dochází $\mathrm{k}$ individuálnímu přístupu trenéra k hráči v tréninku či utkání (Bangsbo 1995). Hoff (2004) tvrdí, že individuální technika, taktika a kondiční připravenost jsou důležitými determinanty při hodnocení rozdílů při sportovním výkonu ve fotbale.

V současné době se $\mathrm{k}$ hodnocení modelu pohybové struktury hráče ve fotbale využívá sofistikovaný sběr a hodnocení dat pomocí počítačové analýzy, která vytváří komplexní profil činností vykonaných během utkání jednotlivými hráči (Drust et al. 2007). Využitím počítačové analýzy můžeme vyhodnotit velký počet sledovaných proměnných, které ovlivňují model pohybové struktury hráčů v utkání. Mezi sledované proměnné v utkání patř́ hráčský post (Barros et al. 2007, Di Salvo et al. 2007), kulturní rozdíly (Rienzi et al. 2000), úroveň hry (Mohr et al. 2003), kvalita týmu (Di Salvo et al. 2009, Rampinini et al. 2007, Rampinini et al. 2009), zápasové zatížení (Odetoyinbo et al. 2008), vyloučení (Carling et al. 2010), střídání (Carling et al. 2010), kondiční připravenost (Krustrup et al. 2003) a věk (Pereira Da Silva 2007) hráčů.

Pomocí počítačové analýzy můžeme monitorovat a vyhodnocovat požadavky na kondiční připravenost hráčů. Na hráče fotbalu jsou kladeny požadavky na vykonávání činností ve velké intenzitě s krátkou dobou odpočinku. Vykonávání pohybových činností ve velké intenzitě při neúplném zotavení během utkání je hlavním rozdílem mezi elitními a průměrnými hráči (Mohr et al. 2003).

Při vytváření tréninkových programů (individuálních, skupinových či hromadných), které mají za cíl rozvíjet či udržovat výkonnost hráče, je důležité respektovat funkční a fyziologické požadavky na jednotlivých postech (Yildrim et al. 2009, Rienzi et al. 2000). Každý hráčský post je charakterizován vlastním pohybový profilem a rozdílnými taktickými požadavky ve vztahu k míči (Mohr et al. 2003, Rampinini et al. 2007), dále to jsou rozdílné požadavky na kondiční, fyziologické a bioenergetické výdaje (Di Salvo et al. 1998, Reilly; Thomas, 1976, Reilly 1997).

Cílem předložené studie je shrnout detailní a sofistikované př́ístupy v hodnocení pohybových nároků a indikátorů na funkční charakteristiky hráče fotbalu. Klíčovými body řešenými v přehledové studii jsou model pohybové struktury hráče v utkání a fyziologické parametry, které mohou ovlivňovat výkon hráče v utkání.

\section{Metodika}

Pro vyhledávání materiálů ke zpracování přehledové studie byly využity internetové databáze Medline (PubMed), ScienceDirect, Web of Science a Scopus.

V internetových databázích byla pro vyhledávání literárních pramenů zvolena klíčová slova: soccer, football, physical demands in soccer, physical demands in football, physiology in soccer, physiology in 
football, fatigue in soccer, fatigue in football, aerobic energy system in soccer, aerobic energy system in football, anaerobic energy system in soccer a anaerobic energy system in football. Výběr použité literatury byl omezen časovým obdobím (od roku 1990), ale starší významné publikace jsou zde uvedeny (Ekblom 1986, Reilly 1976, Withers 1982). Nalezená publikace musela obsahovat plnou verzi znění nebo minimálně strukturovaný abstrakt.

Za stěžejní materiály zabývající se problematikou funkční charakteristiky hráčů fotbalu považujeme publikace The physiology of soccer: with special reference to intense intermittent exercise (Bangsbo 1994), Activity profile of competition soccer (Bangsbo et al. 1991), Match performance of high-standard soccer players with special reference to development of fatigue (Mohr et al. 2003), High-Intensity training in football (Iaia et al. 2009).

\section{Nároky na pohybový výkon v průběhu utkání}

Fotbal je sportovní hra, která je charakterizována intermitentním zatížením (Bangsbo 1995, Krustrup et al. 2005, Krustrup et al. 2006, Mohr et al. 2003, Rampinini et al. 2009, Young et al. 2005). V průběhu utkání hráči vykonají více jak 1200 acyklických a nepředvídatelných změn směrů či běžeckých rychlostí (Mohr et al. 2003). Model pohybové struktury hráče se skládá z chůze, běhů (různých intenzit), skoků, obratů a pádů (Bangsbo 1994, Bangsbo et al. 1991, Krustrup et al. 2006, McInnes et al. 1995, Mohr et al. 2003) a v utkání se opakují každých 3-5 s (Bangsbo et al. 1991, Bangsbo et al. 1994). Z hlediska pohybového výkonu a jeho energetického krytí je důležité sledovat hráče, zda je v útočné či obranné fázi. Mohr et al. (2003) a Rampinini et al. (2007) charakterizují každý hráčský post vlastním pohybovým profilem a rozdílnými taktickými požadavky ve vztahu k míči. Hráčské posty vyžadují také rozdílné kondiční a fyziologické nároky a jsou spjaty či doprovázeny různými energetickými nároky (Di Salvo et al. 1998, Reilly 1997). Model pohybové struktury hráče v utkání zahrnuje kolem 30-40 sprintů (Mohr et al. 2003), více než 700 obratů (Bloomfield et al. 2007), 30-40 pádů a výskoků (Mohr et al. 2003). Součástí utkání jsou i jiné intenzivní činnosti, které doposud nebyly sledovány, jako je dokončení pohybu hráče, vedení míče či kop do míče (Iaia et al. 2009). Podle analýzy modelu pohybové struktury hráče v nejvyšší italské lize (Serie A) bylo zjištěno, že až 75,8 \% běhủ ve vysoké intenzitě (> $19 \mathrm{~km} / \mathrm{hod}$ ) je realizovaných do vzdálenosti $9 \mathrm{~m}$ (Vigne et al. 2010).

Průběh fotbalového utkání vyžaduje vysoké nároky na aerobní i anaerobní připravenost. Hráči opakovaně vykonávají krátké činnosti vysoké intenzity s krátkou a nepravidelnou dobou na zotavení (Rampinini et al. 2009, Bangsbo et al. 2006, Mohr et al. 2003). Vliv na obnovu energetických zdrojů po činnostech vysoké intenzity má rovněž absolvovaná vzdálenost. Bangsbo et al. (2006) zjistil, že hráči $\mathrm{v}$ průběhu utkání po sprintu delším jak $30 \mathrm{~m}$ potřebují delší dobu na zotavení než u průměrně absolvované vzdálenosti sprintem.

Studie (Bangsbo 1994, Bangsbo et al. 1991, Reilly; Thomas 1976, Drust et al. 1998, Mohr et al. 2003) se zabývají pomocí počítačové analýzy (časoprostorové analýzy) celkovou absolvovanou vzdáleností hráče v průběhu utkání. Hráči jsou schopni v utkání absolvovat celkovou vzdálenost kolem 9-12 km. Rozdíl $\mathrm{v}$ absolvované vzdálenosti vzniká podle hráčského postu, plnění taktického úkolu či stylu hry preferovaného týmem. Pohyb hráče v utkání je realizován z 80-90 \% v nízké až střední běžecké intenzitě (pohybová činnost $<15 \mathrm{~km} / \mathrm{hod}$ ) a $10-20 \%$ ve vysoké běžecké intenzitě (pohybová činnost $>15 \mathrm{~km} / \mathrm{hod}$ ) (Bangsbo 1994, Rienzi et al. 2000).

Hráči na mezinárodní či národní elitní úrovni jsou schopni v utkání opakovaně provádět běhy ve vysokých rychlostech o $28 \%(0,53 \mathrm{~km})$ častěji a vykonávat více sprintů o $58 \%(0,24 \mathrm{~km})$ častěji než hráči nižší úrovně. Porovnáme-li výkon hráčů z objemového hlediska, tak celková absolvovaná vzdálenost je u elitních hráčů pouze o 0,5 km větší než u hráčů průměrné úrovně (Reilly; Thomas 1976, Reilly 1990, Bangsbo et al. 1991). Hlavní rozdíl mezi jednotlivými úrovněmi hráčů (elitními, amatérskými, atd.) je ve vykonávání činností ve vysokých intenzitách. 
Graf 1 Model pohybové struktury v dánské lize (Mohr et al., 2003)

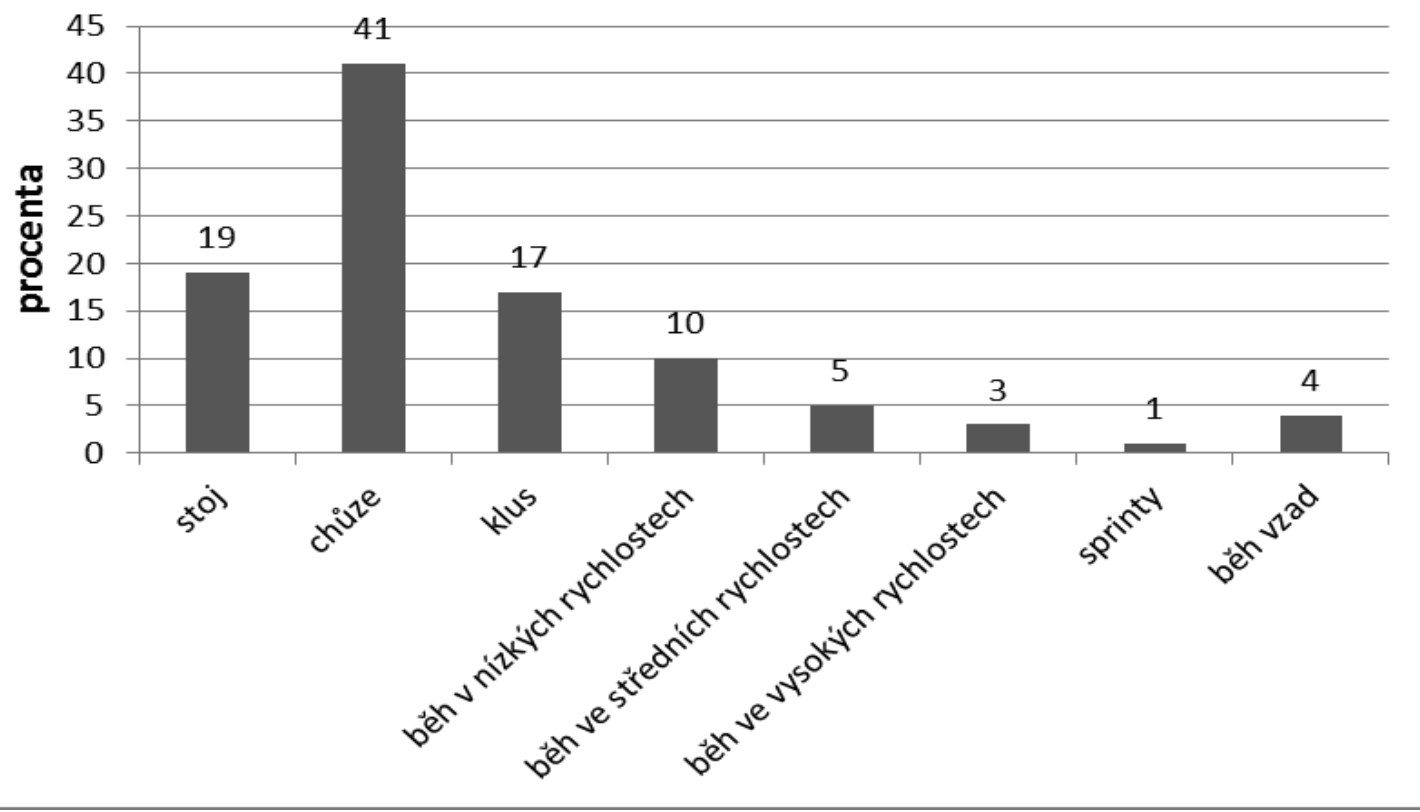

\section{Legenda:}

Stoj - $0 \mathrm{~km} / \mathrm{h}$, chůze: $6 \mathrm{~km} / \mathrm{h}$, klus $-8 \mathrm{~km} / \mathrm{h}$, bèh v nízkých rychlostech $-12 \mathrm{~km} / \mathrm{h}$, běh ve středních rychlostech $-15 \mathrm{~km} / \mathrm{h}$, běh ve vysokých rychlostech $-18 \mathrm{~km} / \mathrm{h}$, sprinty - $30 \mathrm{~km} / \mathrm{h}$

Autoři (Bradley et al. 2009, Di Salvo et al. 2007, Di Salvo et al. 2009, Rampinini et al. 2007, Rampinini et al. 2009) analyzující model pohybové struktury hráče v utkání dělí vykonané činnosti podle těchto rychlostí: stoj $=0 \mathrm{~km} /$ hod, chůze $=6 \mathrm{~km} /$ hod, klus $=8 \mathrm{~km} /$ hod, běh v nízkých rychlostech $=12 \mathrm{~km} /$ hod, běh ve vysokých rychlostech $=15 \mathrm{~km} /$ hod a sprint $=20 \mathrm{~km} /$ hod. Mohr et al. (2003) sledoval i běh ve středních rychlostech (graf 1). Bradley et al. (2011) a Carling (2011) při analyzování pohybu hráče v určitých typech rozestavení sledovali vysokou intenzitu $=14,4-19,7 \mathrm{~km} /$ hod a velmi vysokou intenzitu $\geq$ $19,8 \mathrm{~km} /$ hod.

Pohybové nároky se u jednotlivých hráčů liší podle jednotlivých postů. Každý hráč má v utkání svoji specifickou funkci a roli, které jsou předpokladem pro úspěšné zvládnutí herních úkolů. Např́iklad stř̌ední obránci uběhnou v utkání nejkratší vzdálenost a vykonají nejmenší počet běhů ve vysokých intenzitách (Mohr et al. 2003, Rampinini et al. 2007, Bradley et al. 2009), zatímco krajní obránci a útočníci vykonají významně $(\mathrm{p}<0,05)$ delší sprinty než střední obránci a záložníci (Mohr et al. 2003).

V Tabulce 1 porovnáváme studie (Bangsbo et al. 1991, Castagna et al. 2001, Mohr et al. 2003, Rienzi et al. 2000, Withers et al. 1982), které se zabývaly absolvovanou vzdáleností, pohybovou strukturou a hráčským postem během utkání. Pro přehled uvádíme v Tabulce 2 podle Bradley et al. (2011) a Carling (2011) celkově absolvovanou vzdálenost a vzdálenosti překonané $\mathrm{v}$ určitých intenzitách $\mathrm{v}$ utkání podle postů $\mathrm{v}$ hráčském rozestavení (4-4-2; 4-3-3; 4-5-1). 
Tabulka 1 - Pohybová struktura a absolvovaná vzdálenost hráče fotbalu v utkání

\begin{tabular}{|c|c|c|c|c|c|c|c|c|}
\hline \multirow[b]{2}{*}{ Studie } & \multirow[b]{2}{*}{ Úroveň/země } & \multirow[b]{2}{*}{$\begin{array}{c}\text { Hráčský } \\
\text { post }\end{array}$} & \multirow[b]{2}{*}{$\mathbf{N}$} & \multicolumn{5}{|c|}{ Překonaná vzdálenost $(\mathrm{m})$ podle typu pohybu } \\
\hline & & & & Chůze & Klus & $\begin{array}{l}\text { Běh ve vysokých } \\
\text { rychlostech }\end{array}$ & Sprint & Vzad \\
\hline $\begin{array}{c}\text { Bansgbo et al. } \\
(1991)\end{array}$ & Div $1,2(\mathrm{DEN})$ & & 14 & $3600^{\mathrm{a}}$ & 5200 & 2100 & 300 & \\
\hline $\begin{array}{c}\text { Castagna et } \\
\text { al. (2003) }\end{array}$ & Mládež (ITA) & & 11 & 1144 & 3200 & 986 & 468 & 114 \\
\hline \multirow[t]{6}{*}{$\begin{array}{l}\text { Mohr et al. } \\
(2003)\end{array}$} & Div 1 (DEN) & & 24 & & & 1900 & 410 & \\
\hline & $\begin{array}{l}\text { Top team } \\
\text { (ITA) }\end{array}$ & & 18 & & & 2430 & 650 & \\
\hline & $\begin{array}{l}\text { Kombinace } \\
\text { obou týmů }\end{array}$ & $\mathrm{KO}$ & 9 & & & 2460 & 640 & \\
\hline & & $\mathrm{SO}$ & 11 & & & 1690 & 440 & \\
\hline & & $\mathrm{Z}$ & 13 & & & 2230 & 440 & \\
\hline & & Ú & 9 & & & 2280 & 690 & \\
\hline \multirow[t]{5}{*}{$\begin{array}{c}\text { Rienzi et al. } \\
(2000)\end{array}$} & $\begin{array}{l}\text { Mezinárodní } \\
\text { (JA) }\end{array}$ & & 17 & $3251^{a}$ & $4119^{b}$ & 923 & 345 & \\
\hline & EPL (ENG) & & 6 & $3068^{a}$ & $6111^{b}$ & 887 & 268 & \\
\hline & EPL - cizinci & $\mathrm{O}$ & 9 & $3256^{a}$ & $4507^{b}$ & 701 & 231 & \\
\hline & & $\mathrm{Z}$ & 10 & $3023^{a}$ & $5511^{\mathrm{b}}$ & 1110 & 316 & \\
\hline & & Ú & 4 & $3533^{a}$ & $2746^{\mathrm{b}}$ & 900 & 557 & \\
\hline \multirow[t]{4}{*}{$\begin{array}{c}\text { Withers et al. } \\
(1982)\end{array}$} & NL (AUS) & $\mathrm{KO}$ & 5 & 2839 & 5391 & 1737 & 946 & 1066 \\
\hline & & SO & 5 & 3081 & 3854 & 1271 & 397 & 1556 \\
\hline & & $\mathrm{Z}$ & 5 & 2670 & 6085 & 1841 & 646 & 951 \\
\hline & & Ú & 5 & 3506 & 5224 & 1177 & 682 & 1188 \\
\hline
\end{tabular}

\section{Legenda:}

$N$ - počet probandi̊, DEN - Dánsko, ITA - Itálie, JA - Jižní Amerika, EPL - Anglická Premier League, ENG - Anglie, NL - Národníliga, AUS - Austrálie, KO - krajní obránce, SO - střední obránce, Z - záložník, U - obránce, $a$-zahrnuje chůzi zpět, $b$ - zahrnuje běh stranou a běh vzad 
Tabulka 2 - Porovnání hráčských postů podle rozestavení a zatížení ve vysoké intenzitě

\begin{tabular}{|c|c|c|c|c|c|}
\hline Studie & Systém & Post & Celková vzdálenost & Vysoká rychlost & $\begin{array}{c}\text { Velmi vysoká } \\
\text { rychlost }\end{array}$ \\
\hline $\begin{array}{c}\text { Bradley et al. } \\
(2011)\end{array}$ & $4-4-2$ & $\mathrm{O}$ & $10452 \pm 755$ & $2454 \pm 632$ & $862 \pm 309$ \\
\hline \multirow[t]{2}{*}{$\begin{array}{c}\text { Carling et } \\
\text { al.(2011) }\end{array}$} & & $\mathrm{KO}$ & $10655 \pm 497$ & $1542 \pm 279$ & $843 \pm 128$ \\
\hline & & SO & $10004 \pm 469$ & $1288 \pm 177$ & $470 \pm 108$ \\
\hline $\begin{array}{c}\text { Bradley et al. } \\
\text { (2011) }\end{array}$ & & $\mathrm{Z}$ & $11505 \pm 783$ & $3146 \pm 550$ & $1118 \pm 262$ \\
\hline \multirow[t]{2}{*}{$\begin{array}{c}\text { Carling et } \\
\text { al.(2011) }\end{array}$} & & $\mathrm{KZ}$ & $10543 \pm 656$ & $1478 \pm 270$ & $844 \pm 260$ \\
\hline & & SZ & $11177 \pm 549$ & $2001 \pm 297$ & $658 \pm 151$ \\
\hline $\begin{array}{c}\text { Bradley et al. } \\
(2011)\end{array}$ & & Ú & $9982 \pm 769$ & $2250 \pm 454$ & $950 \pm 236$ \\
\hline $\begin{array}{c}\text { Bradley et al. } \\
(2011)\end{array}$ & $4-3-3$ & $\mathrm{O}$ & $10073 \pm 852$ & $2218 \pm 625$ & $751 \pm 273$ \\
\hline \multirow[t]{2}{*}{$\begin{array}{l}\text { Carling et } \\
\text { al.(2011) }\end{array}$} & & $\mathrm{KO}$ & $10824 \pm 473$ & $1590 \pm 207$ & $911 \pm 153$ \\
\hline & & $\mathrm{SO}$ & $10161 \pm 404$ & $1269 \pm 191$ & $477 \pm 112$ \\
\hline $\begin{array}{c}\text { Bradley et al. } \\
(2011)\end{array}$ & & $\mathrm{Z}$ & $11586 \pm 494$ & $3013 \pm 538$ & $985 \pm 299$ \\
\hline \multirow[t]{2}{*}{$\begin{array}{c}\text { Carling et } \\
\text { al.(2011) }\end{array}$} & & $\mathrm{KZ}$ & $10916 \pm 546$ & $1633 \pm 236$ & $869 \pm 201$ \\
\hline & & SZ & $11278 \pm 446$ & $2029 \pm 319$ & $704 \pm 188$ \\
\hline $\begin{array}{c}\text { Bradley et al. } \\
(2011)\end{array}$ & & Ú & $11130 \pm 999$ & $2988 \pm 614$ & $1155 \pm 231$ \\
\hline $\begin{array}{c}\text { Bradley et al. } \\
(2011)\end{array}$ & $4-5-1$ & $\mathrm{O}$ & $10123 \pm 875$ & $2207 \pm 691$ & $748 \pm 293$ \\
\hline \multirow[t]{2}{*}{$\begin{array}{c}\text { Carling et } \\
\text { al.(2011) }\end{array}$} & & $\mathrm{KO}$ & $10884 \pm 513$ & $1592 \pm 266$ & $848 \pm 158$ \\
\hline & & $\mathrm{SO}$ & $10192 \pm 466$ & $1264 \pm 185$ & $497 \pm 141$ \\
\hline $\begin{array}{c}\text { Bradley et al. } \\
(2011)\end{array}$ & & $\mathrm{Z}$ & $11606 \pm 722$ & $3207 \pm 555$ & $1103 \pm 259$ \\
\hline \multirow[t]{2}{*}{$\begin{array}{c}\text { Carling et } \\
\text { al.(2011) }\end{array}$} & & $\mathrm{KZ}$ & $10948 \pm 650$ & $1591 \pm 263$ & $861 \pm 174$ \\
\hline & & $\mathrm{SZ}$ & $11250 \pm 510$ & $1985 \pm 308$ & $678 \pm 195$ \\
\hline $\begin{array}{c}\text { Bradley et al. } \\
(2011)\end{array}$ & & Ú & $10012 \pm 946$ & $2333 \pm 458$ & $870 \pm 227$ \\
\hline
\end{tabular}

\section{Legenda:}

$O$ - obránce, $Z$ - záložník, Ú - útočník, KO - krajní obránce, KZ - krajní záložník, SO - střední obránce, SZ - střední záložník, Ú - útočník

\section{Aerobní procesy ve fotbale}

Hráči během utkání čerpají energii z 80-90 \% aerobního metabolismu (Bangsbo 1994, Bangsbo et al. 2008, Helgerud et al. 2001), což jim umožňuje pracovat ve vyšších intenzitách po delší časové období. Šetř́i zásoby glykogenu a jsou schopni pracovat ve vyšších intenzitách směrem ke konci utkání (Bangsbo et al. 2008). Navíc aerobní metabolismus minimalizuje pokles v provedení pohybových činností a v kon- 
centraci, které jsou vyvolané únavou v závěru utkání (Bangsbo et al. 2006). Nemají-li dostatečně adaptovaný aerobní metabolismus, dochází v průběhu utkání ke snížení celkové uběhnuté vzdálenosti, více činností je prováděno v nízké intenzitě, snížení koncentrace glukózy a krevního laktátu. K poklesu výše jmenovaných fyziologických parametrů dochází především ve druhém poločase (Ekblom 1986, Tumilty 1993).

Důležitými determinantami při hodnocení aerobní kapacity a aerobního výkonu jsou srdeční frekvence (SF) a maximální spotřeba kyslíku $\left(\mathrm{VO}_{2 \max }\right)$.

Průměrná SF se během utkání pohybuje okolo 85 \% maximální hodnoty (Ali et al. 1991, Ekblom 1986, Krustrup et al. 2005). Bangsbo (1994) a Reilly (1990) interpretují, že průměrná intenzita zatížení u fotbalistů během 90minutového zápasu se pohybuje kolem anaerobního prahu nebo 80-90 \% maximální srdeční frekvence $\left(\mathrm{SF}_{\max }\right)$. Nejvyšší naměřené hodnoty SF se pohybovaly okolo $98 \%$ maximální hodnoty (Ali et al. 1991, Ekblom 1986, Krustrup et al. 2005). Srdeční frekvence během utkání u elitních hráčů neklesne pod $65 \% \mathrm{SF}_{\max }$ (Bangsbo et al. 2002, Krustrup et al. 2004), pokud se neobjeví neobvyklé situace a delší dobu se nehraje (těžké zranění hráče, nevhodné chování fanoušků).

Při hodnocení aerobního výkonu je $\mathrm{VO}_{2 \max }$ důležitou determinantou z hlediska kondiční přípravy hráče (Helgerud et al. 1990, Hoff et al. 2002). Vyšší hodnota $\mathrm{VO}_{2 \max }$ umožňuje hráčům šetřit glykogenové zásoby, které jsou nezbytné k uvolnění energie při činnostech vykonávaných ve vysoké intenzitě nebo př̀i sprintech (Bangsbo et al. 1988). Smaros (1980) dodává, že hodnota $\mathrm{VO}_{2 \max }$ je důležitá především ke konci utkání (posledních 20 minut), kdy dochází k rozhodující fázi. Hodnota $\mathrm{VO}_{2 \max }$ je důležitá i mimo zatížení, nebot urychluje regenerační procesy po utkání či náročné tréninkové jednotce (Bangsbo et al. 1988, Ekblom 1986).

Průměrné hodnoty $\mathrm{VO}_{2 \max }$ jednotlivých týmů, které byly naměřěny v laboratorních podmínkách na běžeckém ergometru, se pohybovaly mezi 56,8 a 67,6 ml/kg/min (Al Hazzaa 2001, Bangsbo et al. 1991, Casajus 2001, Strudwick et al. 2002, Wisloff et al. 1998). Nejvyšší naměřená průměrná hodnota $\mathrm{VO}_{2 \max } \mathrm{V}$ profesionálním fotbalovém týmu byla $67,6 \mathrm{ml} / \mathrm{kg} / \mathrm{min}$ (Wislof et al. 1998). Rozdíly v hodnotách $\mathrm{VO}_{2 \max }$ může způsobovat herní styl, soutěžní úroveň či trénovanost hráčů.

U hráčů v poli (obránci, záložníci a útočníci) se hodnota $\mathrm{VO}_{2 \max }$ pohybuje mezi $50-75 \mathrm{ml} / \mathrm{kg} / \mathrm{min}$ (Wisloff et al. 1998, Casajus 2001). Hlavními důvody rozptýlených hodnot jsou posty hráčů, specifické úkoly a trénovanost hráčů. U brankářů je hodnota $\mathrm{VO}_{2 \max }$ více ustálená a pohybuje se okolo $50-55 \mathrm{ml} /$ $\mathrm{kg} / \mathrm{min}$ (Wisloff et al. 1998, Casajus 2001). Podle hráčských postů jsou největší nároky $\mathrm{VO}_{2 \max }$ kladeny na záložníky, nebot během utkání mají na hřřšti z hlediska pohybového projevu největší akční rádius (Reilly 1990, Tumilty 1993, Wisloff et al. 1998). Jejich úkolem je řídit př̀chodovou fázi (z obranné fáze do útočné a naopak), a tím podporovat spoluhráče $v$ útočné i obranné činnosti

V kondiční přípravě hráče fotbalu je aerobní trénink důležitou součástí. Aerobní trénink vyvolává změny u kardiovaskulárního systému jako je srdeční frekvence, průtok krve srdcem či roztažitelnost tepen (Rakobowchuk et al. 2009). Tyto změny zlepšují schopnost kardiovaskulárního systému přenášet kyslík, což vede k rychlejší svalové a plicní utilizaci kyslíku $\left(\mathrm{O}_{2}\right)$ (Bailey et al. 2009, Krustrup et al. 2004) a vyšší $\mathrm{VO}_{2 \max }$ (Impellizzeri et al. 2006, Ferrari et al. 2008, Helgerud et al. 2001).

Bangsbo et al. (2006) shrnují význam aerobního tréninku do tř́ bodů:

1. Pro zlepšení kapacity kardiovaskulárního systému k přenosu $\mathrm{O}_{2}$, nebot při intenzivnějším zatížení jsou zvýšené požadavky na aerobní metabolismus. Hráči tak mohou pracovat ve větší intenzitě.

2. Ke schopnosti svalů využít kyslík a k oxidaci tuků během delšího zatížení, čímž dochází k ušetření omezeného množství glykogenu.

3. Pro rychlejší schopnost zotavení po činnostech vysoké intenzity.

Ve fotbale je důležité opakovat herní a pohybové činnosti ve velké intenzitě během celého utkání. Hráči po absolvování pohybových či herních činností vysoké intenzity potřebují urychlit regenerační procesy (Bangsbo 1994, Ekblom 1986, Fitzsimmons et al., 1993), obnovit energetické zdroje z důvodu oddálení únavy či schopnosti kvalitně a opakovaně provádět činnosti. Vlivem intermitentního zatížení jsou kladeny zvýšené požadavky na aerobní kapacitu (Krustrup et al. 2003) a aerobní výkon. 


\section{Anaerobní procesy ve fotbale}

Ve fotbalovém utkání je energie převážně hrazena aerobním metabolismem, který je při provádění intenzivních činností v průběhu utkání překrýván anaerobním metabolismem (Mohr et al. 2003, Wragg et al. 2000). Intenzivní činnosti ve fotbale, ve kterých jsou kladeny nároky na anaerobní metabolismus, jsou tvořeny jednak sprinty (různé vzdálenosti či doby trvání), dále výskoky či osobními souboji o míč. V utkání jsou opakované intenzivní činnosti jedním z rozhodujících faktorů o výsledku (Wragg et al. 2000). Hráči elitní úrovně vykonají během utkání od 150 do 250 intenzivních činností v průběhu utkání (Krustrup et al. 2006). Na vykonání intenzivních činností v utkání může mít vliv kvalita soupeře, průběžný stav utkání či únava hráče. Během intenzivních činností v průběhu utkání se snižují zásoby svalového kreatinfosfátu $(\mathrm{CP})$ či hodnoty svalového $\mathrm{pH}$, a postupně dochází ke zvýšení koncentrace krevního laktátu (Krustrup et al. 2006). CP, který se v utkání snižuje během intenzivních činností, se resyntetizuje v následném období nízké intenzity (Bangsbo 1994). Pokud je během utkání větší počet intenzivních činností s krátkou dobou odpočinku, tak hodnota CP je po delší dobu nízká (pod $30 \%$ klidové úrovně) (Krustrup et al. 2005).

Průměrná koncentrace laktátu v krvi v průběhu fotbalového utkání je v rozmezí 2-10 mmol/l s individuálními hodnotami kolem 12 mmol/l (Bangsbo 1994, Krustrup et al. 2006). Každý hráč se v utkání pohybuje odlišnou intenzitou (např. krajní obránce oproti střednímu obránci). Dủležité je poznamenat, že v průběhu prvního poločasu mají hráči vyšší hodnoty krevního laktátu než ve druhém poločase (Tabulka 3). Tento stav může být ovlivňován nastupující únavou v průběhu druhého poločasu, př̀ které dochází k poklesu výkonu hráče ve vysoké intenzitě. Odplavení krevního laktátu je závislé na jeho koncentraci, činnosti probíhající v období regenerace a na aerobní kapacitě organismu (Bangsbo 1994). Hráči s vyššími hodnotami $\mathrm{VO}_{2 \max }$ mohou mít nižší hladinu koncentrace krevního laktátu vzhledem k efektivnějším zotavovacím procesům po zatížení ve vysoké intenzitě (Tomlin et al. 2001).

Bangsbo (1994) zdůrazňuje, že čím jsou vyšší hodnoty krevního laktátu, tím je i rychlost jeho odplavení rychlejší.

Účastí anaerobního metabolismu se zvyšuje aktivita anaerobních enzymů jako jsou kreatinkináza, fosfofruktokináza, myokináza a glykogen fosforyláza (Ross et al. 2001).

Trénink v oblasti anaerobního zatížení ovlivňuje aerobní metabolismus, dochází k rychlejšímu odplavení krevního laktátu a rychlejší obnově CP (Tomlin et al. 2001).

Tabulka 3 - Hodnoty krevního laktátu v průběhu utkání

\begin{tabular}{|c|c|c|c|c|c|c|}
\hline \multirow{2}{*}{ Studie } & \multirow{2}{*}{ Úroveň/země } & \multirow{2}{*}{$\mathbf{N}$} & \multicolumn{2}{|c|}{ Lakát v 1. pol. mmol/l } & \multicolumn{2}{|c|}{ Laktát ve 2. pol. mmol/l } \\
\hline & & & v průběhu & na konci & v průběhu & na konci \\
\hline $\begin{array}{c}\text { Bangsbo et al. } \\
(1991)\end{array}$ & $\begin{array}{c}\text { Divize } 1 \text { a 2/ } \\
\text { Dánsko }\end{array}$ & 14 & $4,9(2,1-10,3)$ & & $\begin{array}{c}3,7 \\
(1,8-5,2)\end{array}$ & $4,4(2,1-6,9)$ \\
\hline \multirow[t]{2}{*}{$\begin{array}{c}\text { Bangsbo } \\
(1994)\end{array}$} & Liga / Dánsko & & $4,1(2,9-6,0)$ & $\begin{array}{c}2,6 \\
(2,0-3,6)\end{array}$ & $\begin{array}{c}2,4 \\
(1,6-3,9)\end{array}$ & $2,7(1,6-4,6)$ \\
\hline & Liga/ Dánsko & & $6,6(4,4-9,3)$ & $\begin{array}{c}3,9 \\
(2,8-5,4)\end{array}$ & $\begin{array}{c}4,0 \\
(2,5-6,2)\end{array}$ & $3,9(2,3-6,4)$ \\
\hline $\begin{array}{l}\text { Capranica et } \\
\text { al. }(2001)\end{array}$ & Mládež/Itálie & 6 & & $\begin{array}{c}3,1-8,1 \\
\text { v prủběhu } \\
\text { zápasu }\end{array}$ & & \\
\hline \multirow[t]{4}{*}{ Ekblom (1986) } & $\begin{array}{l}\text { Divize 1/ } \\
\text { Švédsko }\end{array}$ & & & $\begin{array}{c}9,5 \\
(6,9-14,3)\end{array}$ & & $\begin{array}{c}7,2 \\
(4,6-10,8)\end{array}$ \\
\hline & $\begin{array}{l}\text { Divize } 2 \text { / } \\
\text { Švédsko }\end{array}$ & & & $\begin{array}{c}8,0 \\
(5,1-11,5)\end{array}$ & & $\begin{array}{c}6,6 \\
(3,1-11,0)\end{array}$ \\
\hline & $\begin{array}{l}\text { Divize 3/ } \\
\text { Švédsko }\end{array}$ & & & $\begin{array}{c}5,5 \\
(3,0-12,6)\end{array}$ & & $4,2(3,2-8,0)$ \\
\hline & $\begin{array}{l}\text { Divize 4/ } \\
\text { Švédsko }\end{array}$ & & & $\begin{array}{c}4,0 \\
(1,9-6,3)\end{array}$ & & $3,9(1,0-8,5)$ \\
\hline
\end{tabular}


Únava je definována jako neschopnost udržet opakovaný či očekávaný výkon (Edwards 1983) nebo poklesem fyzické výkonnosti (Enoka et al. 1992) v průběhu utkání.

Během zatížení dochází při vysoké intenzitě ke kumulaci fyziologické únavy, která je charakteristická pro mnoho sportovních týmů, včetně fotbalových. Tento jev je připisován vyčerpání glykogenu ve svalech, snížení cirkulující hladiny glukózy v krvi, hypertermii a ztrátě tělních tekutin (Mohr et al. 2005). Únava se začíná kumulovat ke konci utkání, kdy se snižuje počet činností ve vysoké intenzitě (Krustrup et al. 2006, Mohr et al. 2003, Mohr et al. 2004, Mohr et al. 2005). Snížená teplota svalů či nedostečné rozcvičení před začátkem druhého poločasu může ovlivňovat schopnost vykonávat intenzivní činnosti (Mohr et al. 2005). Nastává-li u hráče únava, tak nedochází pouze ke snižování kondičních předpokladů, ale také k poklesu techniky prováděného pohybu (Rampinini et al. 2007) a zároveň k psychické únavě (Meeusen et al. 2006). Zvýšená míra únavy má malý vliv na náladu či mentální výkon (Collardeau et al. 2001), ale i menší úbytky v psychické rovnováze mohou významně ovlivnit výsledek utkání (Meeusen et al. 2006). Nejvýraznější pokles vysoké intenzity byl pozorován v posledních 15 minutách utkání (Mohr et al. 2003, Rienzi et al. 1998). Studie (Bangsbo 1994, Bangsbo et al. 1991, Mohr et al. 2003) uvádějí, že ve druhém poločase fotbalového utkání se snižuje počet sprintů, běhů ve vysokých rychlostech a celková absolvovaná vzdálenost na rozdíl od prvního poločasu. Rampinini et al. (2007) sledovali hráče v italské lize a posuzovali vliv únavy na technické provedení herních činností jednotlivce (vedení míče, střelba, přihrávání). Herní činnosti jednotlivce se ve druhém poločase v porovnání s prvním snížily. Autoři (Ekblom 1986, Tumilty 1993) zjistili změny ve funkčních i fyziologických parametrech. V druhém poločase dochází ke snížení činností ve vysokých intenzitách, poklesu SF, snížení hladiny glukózy v krvi a koncentrace krevního laktátu v porovnání s prvním poločasem. Po intenzivním zatížení vzniká zvýšená únava, která je pro organismus škodlivá.

Důležitým aspektem při oddalování únavy je dodržovat životosprávu. Př́ičinou únavy před koncem utkání může být deplece glykogenu v krvi, játrech či jednotlivých svalových vláknech. Vytvoření nutriční strategie a tréninkového plánu je důležité pro zvýšení zásob svalového glykogenu před utkáním. V tréninkové jednotce před utkáním musíme brát ohled na minimální snížení svalového glykogenu (Bangsbo et al. 2007).

\section{Závěr}

Cílem předložené studie bylo shrnout detailní a sofistikované prŕstupy v hodnocení pohybových nároků a indikátorů na funkční charakteristiky hráčů fotbalu. Studie je zaměřena na prezentaci výsledků představující model struktury pohybového výkonu z hlediska vlastní realizace v souvislosti s energetickou náročností a následným efektem únavy. Velké množství studií zabývajících se touto problematikou ukazuje, o jak důležitý problém se ve fotbale jedná. Stoupající počet studií v průběhu posledních let a větši zaměření na detailní pozorování a hodnocení výkonu hráče v utkání poukazuje na nezbytnost pochopení a vytvoření vztahových souvislostí dané problematiky. Tak jako se neustále zvyšují nároky na jednotlivé hráče a jejich pohybový výkon v utkání, stejně narůstají požadavky na jejich připravenost z hlediska tréninkové zátěže. Pouze detailní pochopení potřeb z hlediska realizace pohybového zatížení v utkání může specifikovat potřeby pro tréninkový proces. Sofistikované metody diagnostiky individuální připravenosti pro herní výkon mohou vytvořit základ evaluace jednotlivých hráčů a týmů. Stejně tak lze tímto způsobem porovnávat intraindividuální změny vybraných parametrů každého hráče vzhledem k jednotlivým obdobím sezóny (př́ípravné období, soutěžní období apod.), nebo porovnávat jednotlivé hráče a týmy mezi sebou. Jasnou snahou je stálé zvyšování kvantitativně měřitelných parametrů, kterého lze dosáhnout jediným systematickým působením, kterým je trénink. Hodnocení vlivu tréninkového procesu vzhledem k pohybovému výkonu lze uskutečňovat pomocí sofistikované evaluace vybraných kvantifikovatelných parametrů.

Tréninkový proces by měl být vytvářen na základě činností probíhajících v utkání.

Hráčské posty jsou charakterizovány odlišnými nároky v modelu pohybové struktury či bioenergetického výdeje a při plánování tréninkového procesu by se měly tyto aspekty respektovat. Hráči během utkání musí v krátkém časovém intervalu reagovat na změny směru či udržovat fotbalovou lokomoci na 
žádoucí úrovni. Důležitou roli v utkání zaujímá týmové pojetí hry a strategie určená trenérem, jenž může souviset s energetickými či pohybovými požadavky na jednotlivé posty.

Během utkání se překrývají aerobní a anaerobní metabolismus z hlediska intenzity zatížení. Hráč musí v utkání provádět opakovaně činnosti ve vysoké intenzitě s rychlou obnovou energetických zdrojů a maximálním oddálením nastupující únavy. Rozdíl mezi hráči elitní a nižší úrovně je ve vykonávání činností ve vysokých intenzitách. Vlivem únavy ke konci utkání u hráčů dochází ke snížení úrovně jemné koordinace a v provedení pohybových činností.

$\mathrm{Na}$ základě přehledových studií byly zjištěny determinanty a různé pohledy na funkční připravenost hráče. Dominantní úlohu sehrávají následující kritéria: hráčská úroveň (profesionál, amatér apod.), soutěž (mezinárodní, národní apod.), hráčský post, úkoly hráče, fáze utkání a herní systém.

\section{Literatura:}

AL HAZZAA, H. M.; ALMUZAINI, K. S.; AL REFAEE, S. A. Aerobic and anaerobic power characteristics of Saudi elite soccer players. Journal of Sports Medicine and Physical Fitness, 2001, roč. 41, č. 1, s. 54 $-61$.

ALI, A.; FARALLY, M. Recording soccer players' heart rate during matches. Journal of Sports Sciences, 1991, roč. 9, č. 2, s. $183-189$.

BAILEY, S.; WILKERSON, D.; DIMENNA, F.; JONES, A. Influence of repeated sprint training on pulmonary $\mathrm{O}_{2}$ uptake and muscle deoxygenation kinetics in humans. Journal Applied Physiology, 2009, roč. 106 , č. 6 , s. $1875-87$.

BANGSBO, J. The physiology of soccer: with special reference to intense intermittent exercise. Acta Physiology Scandinavia, 1994, roč. 151, č. Suppl (619)., s. 1 - 155.

BANGSBO, J. Fitness training in football:A Scientific Approach. Bagsvaerd : HO + Storm, 1995.

BANGSBO, J.; GIBALA, M.; KRUSTRUP, P.; GONZÁLEZ - ALONSO, J.; SALTIN, B. Enhanced pyruvate dehydrogenase activity does not affect muscle $\mathrm{O}_{2}$ uptake onset of intense exercise in humans. American Journal of Physiology, 2002, roč. 282, č. 1, s. R273 - R280.

BANGSBO, J.; IAIA, F. M.; KRUSTRUP, P. (2007) Metabolic response and fatigue in soccer. International Journal of Sports Physiology and Performance, 2007, roč. 2, č. 2, s. 111 - 127.

BANGSBO, J.; IAIA, F.; KRUSTRUP, P. The yo- yo intermittent recovery test: A useful tool for evaluation of physical performance in intermittent sports. Sports of Medicine, 2008, roč. 38, č. 2, s. 37 - 51.

BANGSBO, J.; JUEL, C.; HELLSTEN, Y.; SALTIN, B. Dissociation between lactate and proton exchange in muscle during intense exercise in man. Journal of Physiology, 1997, roč. 24, č. 7, s. $489-499$.

BANGSBO, J.; MIZUNO, M. Morphological and metabolic alternations in soccer players with detraining and retraining and their relation to performance. In Science and Football. London/New York : E and FN Spon, 1988, s. $114-124$.

BANGSBO, J.; MOHR, M.; KRUSTRUP, P. Physical and metabolic demands of training and match - play in the elite football player. Journal of Sports Sciences, 2006, roč. 24, č. 7, s. 665 - 674.

BANGSBO, J.; NORREGAARD, L.; THORSOE, F. Activity profile of competition soccer. Canadian Journal of Applied Sports Sciences, 1991, roč. 16, č. 2, s. 110 - 116.

BARROS, R. M. L.; MISUTA, M. S.; MENEZES, R. P.; FIGUEROA, P. J.; MOURA, F. A.; CUNHA, S. A.; ANIDO, R.; LEITE, N. J. Analysis of the distances covered by first division Brazilian soccer players obtained with an automatic tracking method. Journal of Sports Science and Medicine, 2007, roč. 6, č. 2, s. $233-242$.

BLOOMFIELD, J.; POLMAN, R.; O'DONOGHUE, P. Physical demands of different positions in FA Premier League soccer. Journal of Sports Science and Medicine, 2007, roč. 6, č. 1, s. 63 - 70.

BRADLEY, P. S.; CARLING, CH.; ARCHER, D.; ROBERTS, J.; DODDS, A.; MASCIO, M.; PAUL, D.; DIAZ, A. G.; PEART, D.; KRUSTRUP, P. The effect of playing formation on high-intensity running and technical profiles in English FA Premier League soccer matches. Journal of Sports Sciences, 2011, roč. 29, č. 8, s. $821-830$. 
BRADLEY, P.; SHELDON, W.; WOOSTER, B.; OLSEN, P.; BOANAS, P.; KRUSTRUP, P. High-intensity running in English FA Premier League soccer matches. Journal of Sports Sciences, 2009, roč. 27, č. 2, s. $159-168$.

CAPRANICA, L.; TESSITORE, A.; GUIDETTI, L.; FIGURA, F. Heart rate and match analysis in pre-pubescent soccer players. Journal of Sports Sciences, 2001, roč. 19, č. 6, s. 379 -84.

CARLING, CH. Influence of opposition team formation on physical and skill-related performance in a professional soccer team. European Journal of Sport Science, 2011, roč. 11, no. 3, s. 155 - 164.

CARLING, CH.; ESPIÉ, V.; LE GALL, F.; BLOOMFIELD, J.; JULLIEN, H. Work-rate of substitutes in elite soccer: A preliminary study. Journal of Science and Medicine in Sport, 2010, roč. 13, č. 2, s. 253 - 255.

CASAJUS, J. A. Seasonal variation in fitness variables in professional soccer players. Journal of Sports Medicine and Physical Fitness, 2011, roč. 41, č. 4, s. 463 - 469.

CASTAGNA, C.; D'OTTAVIO, S.; ABT, G. Activity profile of young soccer players during actual match play. Journal of Strength and Conditioning Research, 2003, roč. 17, č. 4, s. 775 - 780.

COLLARDEAU, M.; BRISSWALTER, J.; VERCRUYSSEN, F.; AUDIFFREN, M.; GOUBAULT, C. Single and choice reaction time during prolonged exercise in trained subjects: Influence of carbohydrate availability. European Journal of Applied Physiology, 2001, roč. 86, č. 2, s. 150 - 156.

DI SALVO, V.; BARON, R.; TSCHAN, H.; CALDERON MONTERO, F. J.; BACH, N.; PIGOZZI, F. Performance characteristics according to playing position in elite soccer. International Journal of Sports Medicine, 2007, roč. 28, č. 3, s. $222-227$.

DI SALVO, V.; GREGSON, W.; ATKINSON, G.; TORDOFF, P.; DRUST, B. Analysis of high intensity activity in Premier League soccer. International Journal of Sports Medicine, 2009, roč. 30, č. 3, s. 205 - 212.

DI SALVO, V.; PIGOZZI, F. Physical training of football players based on their positional roles in the team. Journal of Sports Medicine and Physical Fitness, 1998, roč. 38,

č. 4, s. 294-297.

DRUST, B.; ATKINSON, G; REILLY, T. Future perspectives in the evaluation of the physiological demands of soccer. Sports Medicine, 2007, roč. 37, č. 9, s. $783-805$.

DRUST, B.; REILLY, T.; RIENZI, E. Analysis of work rate in soccer. Sports Exercise and Injury, 1998, roč. 4, č. 4, s. $151-155$.

EDWARDS, R. H. Biochemical bases of fatigue in exercise performance. In Biochemistry of Exercise. Champaign IL : Human Kinetics Books, 1983, s 3 - 28.

EKBLOM, B. Applied physiology of soccer. Sports Medicine, 1986, roč. 3, č. 1, s. 50 - 60.

ENOKA, R. M.; STUART, D. G. Neurobiology of muscle fatigue. Journal Applied Physiology, 1992, roč. 72 , č. 5, s. $1631-1648$.

FERRARI, B. D.; IMPELLIZZERI, F. M.; RAMPININI, E.; CASTAGNA, C.; BISHOP, D.; WISLOFF, U. Sprint vs. interval training in football. International Journal of Sports Medicine, 2008, roč. 29, č. 8, s. 668 -674 .

FITZSIMMONS, M.; DAWSON, B.; WARD, D.; WILKINSON, A. Cycling and running tests of repeated sprint ability. Australian Journal of Science and Medicine in Sport, 1993, roč. 25, č. 4, s. 82 - 87.

HELGERUD, J.; ENGEN, L. C.; WISLOFF, U.; HOFF, J. Aerobic endurance training improves soccer performance. Medicine and Science in Sports and Exercise, 2001, roč. 33,

č. 11, s. 1925 - 1931.

HELGERUD, J.; INGJER, F.; STROMME, S. B. Sex differences in performance - matched marathon runners. European Journal of Applied Physiology, 1990, roč. 61, č. 5 - 6, p. 433 - 439.

HOFF, J.; GRAN, A.; HELGERUD, J. Maximal strength training improves aerobic endurance performance. Scandinavian Journal of Medicine and Science in Sports and Exercise, 2002, roč. 12, č. 5, s. 288 $-295$.

HOFF, J.; HELGERUD, J. Endurance and strength training for soccer players: Physiological considerations. Sports Medicine, 2004, roč. 34, č. 3, s. 165 - 180. 
HOFF, J.; HELGERUD, J.; WISLOFF, U. Endurance training into the next millenium: Muscular strength training effects on aerobic endurance performance. American Journal of Medicine and Sports, 2002b, roč. 4 , č. 1 s. $58-67$.

IAIA, M. I.; RAMPININI, E.; BANGSBO, J. High-Intensity training in football. International Journal of Sports Physiology and Performance, 2009, roč. 4, č. 3, s. $291-306$.

IMPELLIZZERI, F.; MARCORA, S.; CASTAGNA, C.; REILLY, T.; SASSI, A.; IAIA, F. M.; RAMPININI, E. Physiological and performance effects of generic versus specific aerobic training in soccer players. International Journal of Sports Medicine, 2006, roč. 27,

č. 6 , s. $483-492$.

KRUSTRUP, P.; HELLSTEN, Y.; BANGSBO, J. Intense interval training enhances human skeletal muscle oxygen uptake in the initial phase of dynamic exercise at high but not at low intensities. Journal of Physiology, 2004, roč. 559, č. 1, s. $335-345$.

KRUSTRUP, P.; MOHR, M.; AMSTRUP, T.; RYSGAARD, T.; JOHANSEN, J.; STEENSBERG, A.; PEDERSEN, P. K.; BANGSBO, J. The yo-yo intermittent recovery test: Physiological response, reliability and validity. Medicine and Science in Sport and Exercise, 2003, roč. 35, č. 4,s. 697 - 705.

KRUSTRUP, P.; MOHR, M.; ELLINGSGAARD, H.; BANGSBO, J. Physical demands of elite female soccer game: importance of training status. Medicine and Science in Sports and Exercise, 2005, roč. 37, č. 7, s. $1242-1248$.

KRUSTRUP, P.; MOHR, M.; STEENSBERG, A.; BENCKE, J; KJAER, M.; BANGSBO, J. Muscle and blood metabolities during a soccer game: implications for sprint performance. Medicine and Science in Sports and Exercise, 2006, roč. 38, č. 6, s. 1 - 10.

MCINNES, S. E.; CARLSSON, J. S.; JONES, C. J.; MCKENNA, M. J. The physiological load imposed on basketball players during competition. Journal of Sports Sciences, 1995, roč. 13, č. 1, s. 387 - 397.

MEEUSEN, R.; WATSON, P.; DVORAK, J. The brain and fatigue: New opportunities for nutritional interventions? Journal of Sports Sciences, 2006, roč. 24, č. 7, s. $773-782$.

MOHR, M.; KRUSTRUP, P.; BANGSBO, J. Match performance of high - standard soccer players with special reference to development of fatigue. Journal of Sports Sciences, 2003, roč. 21, č. 7, s. 519 - 528.

MOHR, M.; KRUSTRUP, P.; BANGSBO, J. Fatigue in soccer: A brief review. Journal of Sports Sciences, 2005, roč. 23, č. 6, s. $593-599$.

MOHR, M.; KRUSTRUP, P.; NYBO, L.; NIELSEN, J. J.; BANGSBO, J. Muscle temperature and sprint performance during soccer matches-beneficial effects of re-warm-up at a half time. Scandinavian Journal of Medicine and Science in Sports, 2004, roč. 14, č. 3,

s. $156-162$.

ODETOYINBO, K., WOOSTER, B., LANE, A. The effect of a succession of matches on the activity profiles of professional soccer players. In Science and football VI. Abingdon : UK, 2008, s. 105 - 111.

PEREIRA DA SILVA, N., KIRKENDALL, D. T., LEITE DE BARROS NETO, T. Movement patterns in elite Brazilian youth soccer. Journal of Sports Medicine and Physical Fitness, 2007, roč. 47, č. 3, s. 270 - 275. RAKOBOWCHUK, M.; STUCKEY, M. I.; MILLAR, P. J.; GURR, L.; MACDONALD, M. J. Effect of acute sprint interval exercise on central and peripheral artery distensibility in young healthy males. European Journal of Applied Physiology, 2009, roč. 105, č. 5,

s. $787-795$.

RAMPININI, E.; COUTSS, A. J.; CASTAGNA, C.; SASSI, R.; IMPELLIZZERI, F. Variation in top level soccer match performance. International Journal of Sports Medicine, 2007, roč. 28, č. 12, s. 1018 - 1024.

RAMPININI, E.; IMPELLIZZERI, F. M.; CASTAGNA, C.; COUTSS, A. J.; WISLOFF, U. Technical performance during soccer matches of the Italian Serie A league: effect of fatigue and competitive level. Journal of Sports Science and Medicine, 2009, roč. 12, č. 1,

s. $227-233$.

REILLY, T. Football. In Physiology of sports. London : E \& FN Spon, 1990, s. $371-426$.

REILLY, T. Energetics of high-intensity exercise (soccer) with particular reference to fatigue. Journal of Sports Sciences, 1997, roč. 15, č. 3, s. 143-144. 
REILLY, T.; THOMAS, V. (1976) A motion analysis of work-rate in different positional roles in professional football match-play. Journal of Human Movement Studies, 1976, roč. 2, s. 87 - 97.

RIENZI, E.; DRUST, B.; REILLY, T.; CARTER, J. E. L.; MARTIN, A. Investigation of anthropometric and work-rate profiles of elite South American international soccer players. Journal Sports of Medicine and Physical Fitness, 1998, roč. 40, č. 2, s. 162 - 169.

ROSS, A.; LEVERITT, M. Long-term metabolic and skeletal muscle adaptions to short-sprint trainig: implications for sprint training and tapering. Sports Medicine, 2001, roč. 31, č. 15, s. $1063-1082$.

SILVA, A. S. R.; SANTHIAGO, V.; PAPOTI, M.; GOBATTO, C. A. Hematological parameters and anaerobic threshold in Brazilian soccer players throughout a training program. International Journal of Laboratory Hematology, 2008, roč. 30, č. 2, s. 158 - 166.

SMAROS, G. Energy usage during a football match. In Proceedings of the 1 st International Congress on Sports Medicine Apllied to football. Roma : Vecchiet L, 1980, s. 795 - 801.

STRUDWICK, A.; REILLY, T.; DORAN, D. Anthropometric and fitness profiles of elite players in two football codes. Journal Sports of Medicine and Physical Fitness, 2002, roč. 42, č. 2, s. $239-242$.

TOMLIN, D. L.; WENGER, H. A. The relationship between aerobic fitness and recovery from high intensity exercise. Sports Medicine, 2001, roč. 31, č. 1, s. 1 - 11.

TUMILTY, D. Physiological characteristics of elite soccer players. Sports Medicine, 1993, roč. 16, č. 2, s. $80-96$.

VIGNE, G.; GAUDINO,C.; ROGOWSKI, I.; ALLOATTI, G.; HAUTIER, C. Activity profile in elite Italian Soccer Team. International Journal of Sports Medicine, 2010, roč. 31, č 5,

s. 304-310.

WISLOFF, U.; HELGERUD, J.; HOFF, J. Strength and endurance of elite soccer players. Medicine and Science in Sports and Exercise, 1998, roč. 30, č. 3, s. $462-467$.

WITHERS, R. T.; MARICIC, Z.; WASILEWSKI, S.; KELLY, L. (1982) Match analysis of Australian professional soccer players. Journal of Human Movement Studies, 1982, roč. 8, s. 159 - 176.

WRAGG, C. B.; MAXWELL, N. S.; DOUST, J. H. Evaluation of the reliability and validity of a soccer-specific field test of repeated sprint ability. European Journal of Applied Physiology, 2000, roč. 83, č. 1, s. 77-83.

YILDRIM, A.; EMRE, A. K.; KORKUSUZ, F.; CICEK, S. Physiological profiles of soccer players with respect to playing positions. In Science and Football VI: TheProceedings of the Sixth World Congress on Science and Fotball. London : Routledge, 2009, s. 370 - 373.

YOUNG, W. B.; NEWTON, R. U., DOYLE; T. L.; CHAPMAN, D.; CORMACK, S.; STEWART, G; DAWSON, B. Physiological and anthropometric characteristics of starters and non-starters and playing positions in elite Australian Rules football: a case study. Journal of Science and Medicine in Sport, 2005, roč. 8 , č. 3 , s. $333-345$. 